\title{
Justiça de transição, memória e verdade: histórias de vida de militantes comunistas e a Comissão Municipal da Verdade de João Pessoa
}

\author{
Monique Cittadino* \\ ORCID iD 0000-0002-2182-4354 \\ Univer sidade Federal da Paraíba, Departamento de História/CCHLA, João Pessoa, Brasil \\ Rodrigo Freire de Carvalho e Silva* \\ ORCID iD 0000-0003-1409-6368 \\ Universidade Federal da Paraíba, Departamento de Ciências Sociais/CCHLA, João Pessoa, Brasil
}

\begin{abstract}
Resumo: Este trabalho pretende discutir, a partir da experiência da Comissão Municipal da Verdade de João Pessoa (CMV-JP) (2014-2018), as histórias de vida de militantes comunistas perseguidos durante a ditadura militar (1964-1985). Tendo em vista os conceitos de justiça de transição e direito à memória e à verdade, a CMV-JP realizou oitivas com as vítimas da repressão valendo-se da metodologia da História de Vida, de forma que os depoimentos concedidos não se limitaram a tratar especificamente das violaçóes ocorridas no período ditatorial, mas permitiram que aflorassem memórias mais antigas, recordaçóes familiares e da militância comunista, para culminarem nos relatos das perseguiçóes sofridas, contribuindo para a produção de uma Memória esquecida e para a enunciação de uma Verdade encoberta pelos relatos oficiais.
\end{abstract}

Palavras-chave: Justiça de transiçẫo. História de Vida. Militantes comunistas. Comissão Municipal da Verdade de Joáo Pessoa.

Doutora em História Econômica pela Universidade de São Paulo (USP), com orientação do Prof. Dr. José Jobson de Andrade Arruda. E-mail: monique@garibaldijpa.com.br.

* Doutor em Ciências Sociais pela Universidade de Brasília (UnB), com orientação do Prof. Dr. David Fleischer. E-mail: rfreirecs@hotmail.com. 


\title{
Transitional justice, memory and truth: communist activists' life stories and the Municipal Truth Comission of João Pessoa
}

\begin{abstract}
This paper intends to discuss, based on the experience of the Municipal Truth Commission of João Pessoa (CMV-JP) (2014-2018), the life stories of communist actvists persecuted during the military dictatorship (1964-1984). Bearing in mind the concepts of transitional justice and right to memory and truth, the CMV-JP held interviews with victims of repression using the methodology of Life History, so that the testimonies granted were not limited to dealing specifically with the violations that occurred during the dictatorial period, but allowed to bring up older memories, family memories and communist militancy, to culminate in the reports of the persecutions suffered, contributing to the production of a forgotten Memory and to the enunciation of a Truth covered by official reports.
\end{abstract}

Keywords: Transitional justice. Life History. Communist activists. Municipal Truth Commission of João Pessoa.

\section{Justiça de transição, memória e verdade}

A criação da Comissão Nacional da Verdade (CNV) em 2012,1 e das diversas outras comissōes correlatas instaladas subsequentemente no país, ao buscar a verdade sobre os crimes perpetrados por agentes do Estado contra seus cidadáos durante a ditadura militar instalada em 1964, representou um avanço nas tarefas da justiça de transição no país. Conceito desenvolvido entre os anos 1980 e 1990, a justiça de transiçấo relaciona-se aos processos de superação de uma situação ditatorial rumo ao estabelecimento de uma democracia e, historicamente, surgiu em funçấo dos dilemas e das dificuldades em se lidar com um passado recente marcado por conflitos e violaçóes sistemáticas aos direitos humanos, no momento em que diversos países saiam de

\footnotetext{
A CNV foi fruto de Projeto de Lei (PL) enviado ao Congresso Nacional em maio de 2010 pelo então presidente da República, Luiz Inácio Lula da Silva. Em novembro de 2011, após aprovação parlamentar, o PL foi sancionado pela presidenta Dilma Rousseff e transformado na Lei n ${ }^{\circ}$ 12.528/2011.Em março de 2012, a CNV foi instalada. A busca pela reparação às vítimas de violações de direitos humanos e pela memória, verdade e justiça remete aos anos da ditadura militar, com a criação do Comitê Brasileiro pela Anistia (CBA), em 1978, e a atuação dos grupos de familiares de mortos e desaparecidos políticos, além de grupos de defesa dos direitos humanos, como o Brasil: Nunca Mais (BNM) e as Comissões de Justiça e Paz. A partir de 1995, com a criação da Comissão Especial sobre Mortos e Desaparecidos Políticos (CEMDP), o Estado brasileiro passou a se dedicar às tarefas de reconhecimento e reparação das vítimas da ditadura militar e das suas famílias, além de iniciar o trabalho de localização dos corpos dos desaparecidos políticos, que tive sequência com a Comissão de Anistia (2002). A XI Conferência Nacional de Direitos Humanos (2008) incluiu entre suas recomendações a criação de uma Comissão Nacional da Verdade e da Justiça, advogando pela responsabilização dos envolvidos nas graves violações de direitos humanos durante a ditadura militar. Tal demanda de responsabilização dos agentes do Estado, que não foi incorporada na lei que criou a CNV, foi largamente praticada nas experiências de justiça de transição dos países do Cone Sul (Argentina, Chile e Uruguai) que vivenciaram ditaduras militares nas décadas de 1970 e 1980, ao contrário da África do Sul pós-apartheid, que priorizou a verdade e a reconciliação.
} 
experiências políticas autoritário-violentas e necessitavam constituir novos pactos de convivência social (Arthur, 2011).

Assim, no escopo da justiça de transição se faz necessário transformar o ambiente autoritário em direção a uma cultura política identificada com os ideais da democracia, paz, tolerância e respeito aos direitos humanos. Para Paul van Zyl, além de processar os perpetradores, cabe à justiça transicional "revelar a verdade sobre crimes passados, conceder reparaçôes às vítimas, reformar as instituiçôes perpetradoras de abuso e promover a reconciliaçáa” (Zyl, 2011, p. 49). Dessa forma, o direito do cidadáo de conhecer a verdade oficial sobre os crimes cometidos "pode ajudar a sensibilizar as futuras geraçóes contra o revisionismo e dar poder aos cidadãos para que reconheçam e oponham resistência a um retorno às práticas abusivas (Zyl, 2011, p. 51)”. Com isso, a justiça de transiçấo opera com duas perspectivas temporais: a do passado, no sentido de trazer a verdade à luz, e a do futuro, ao promover a defesa da democracia e da premissa de que os abusos não tornem a se repetir:

O objetivo principal e primordial de uma justiça de transição [...] é evitar a repetição do que aconteceu, e o seu lema é 'nunca mais' ou a 'educação para o não-retorno'. É uma tentativa para esconjurar ou desafiar a reversibilidade dos acontecimentos históricos, colocando (pelo que é humanamente possível) um ponto firme, uma virada de página, um ponto de não-retorno, uma cláusula pétrea no pacto social que funda um Estado Democrático de Direito. (Tosi, 2014, p. 45).

Não submeter os responsáveis por violaçôes de direitos humanos à responsabilização penal pode ser visto como um elemento limitador dos processos de justiça de transição, dificultando a construção de uma nova cultura política democrática, além de uma nova institucionalidade fundada no Direito, onde não haja espaço para a impunidade e para a autoanistia. As consequências dessa limitação são percebidas no caso brasileiro, em que as forças de segurança continuaram ostentando um alto grau de letalidade ilegal mesmo após a reconstruçáo democrática, com a Constituiçáo Federal de 1988.

$\mathrm{Na}$ perspectiva de contribuir para uma narrativa fundada na verdade sobre as violaçóes aos direitos humanos durante a ditadura militar, contraposta à versão oficial dos fatos e ao silêncio construído localmente, garantindo, portanto, às vítimas dos abusos o "privilégio de poder falar" (Bauer, 2017, p. 167) e cumprindo, assim, uma tarefa de justiça de transição, a Comissão Municipal da Verdade de João Pessoa (CMVJP) foi criada em agosto de 2013, através da Lei $\mathrm{n}^{\circ} 12.633$, e instalada em abril de 2014. Ao longo do período em que atuou, a CMV-JP trabalhou com uma extensa pesquisa documental em arquivos públicos, como o Arquivo da Câmara dos Vereadores e o da Prefeitura Municipal de João Pessoa, da Universidade Federal Fluminense (UFF) e do Arquivo Nacional, onde estáo depositados documentos produzidos pelos extintos Conselho de Segurança Nacional (CSN), Comissão Geral de Investigaçóes (CGI) e Serviço Nacional de Informaçóes (SNI). Ainda foram consultados jornais locais e 
nacionais. Além disso, assumiram especial destaque os depoimentos prestados por militantes de esquerda atingidos pelo aparato repressivo da ditadura. ${ }^{2}$ Para efeito deste artigo, serão utilizados os depoimentos de seis ex-militantes que integravam o Partido Comunista Brasileiro (PCB) de Joăo Pessoa em 1964 e o da cunhada de um militante já falecido no momento de atuação da CMV-JP.

Com relação a tais depoimentos, a CMV-JP optou pela realização de oitivas privadas, não abertas ao público. Tais oitivas valeram-se do recurso à metodologia da história oral, na modalidade de "história de vida" (Queiroz, 1988; Pollak, 1992; Delgado, 2010), em que os depoentes discorreram de forma aberta e espontânea sobre a sua trajetória de vida desde a infância, abordando aspectos da sua constituiçăo familiar, formação escolar e profissional, relaçóes sociais e afetivas, visão de mundo e inserção no universo político. Em nenhum caso se trabalhou com um roteiro prévio de perguntas, evitando-se incorrer, conforme critica Bauer (2017, p. 74), na cobrança de concisão aos depoentes, "ignorando suas subjetividades em uma situação inédita para muitos". Dessa forma, apenas colocou-se inicialmente que o interesse da Comissão incluía também a escuta das respectivas trajetórias de vida dos depoentes. Isso estabeleceu um diálogo livre entre os depoentes e os membros da Comissão, estes responsáveis por fornecer "estímulos" para que aqueles, protagonistas do processo, construíssem suas próprias narrativas (Meihy; Seawright, 2020, p. 63). Tal diálogo evoluía de acordo com a dinâmica do próprio depoimento, o que permitiu a construçáo de relatos de duração variável, alguns se estendendo a mais de uma sessão. Nesse sentido, o recurso à história de vida permitiu que a CMV-JP trabalhasse com um intervalo de memória mais ampla dos depoentes, náo restrito a um único momento de suas vidas, aquele especificamente relacionado à ditadura militar. Assim, os relatos obtidos propiciaram um campo alargado de informaçóes e experiências acerca do universo em que estiveram inseridos tais depoentes, destacando a percepção da cultura política com a qual se identificavam (Soihet; Bicalho; Gouvêa, 2005; Motta, 2018). Ainda, tendo em consideração Tolentino (2014), que analisou as memórias publicizadas e as silenciadas de sobreviventes de um episódio repressivo ocorrido durante a ditadura militar argentina confrontando-as com as narrativas consagradas a respeito de tal episódio, em uma manifestaçáo do "conflito de memórias", podemos afirmar que os relatos fornecidos à CMV-JP possibilitaram àqueles que os pronunciaram que pudessem expressar não só as violências de que foram vítimas no pós-1964, como também as suas versôes dos fatos ocorridos naquele período e, com isso, tivessem reconhecidas publicamente as suas histórias e as suas participações naqueles eventos, inserindo-as nas narrativas até então existentes. Tal perspectiva é compartilhada por Bauer (2017, p. 90-91) para quem "o reconhecimento possibilitaria a elaboraçáo do trauma individual e coletivo, e conformaria novos parâmetros éticos e morais para o convívio em sociedade", de forma que processos como os conduzidos por

2 O relatório final da comissão foi concluído em julho de 2019. Ver: CMV-JP (2020). 
comissóes da verdade "possuiriam uma virtude reparadora, preventiva e pedagógica, que extrapolaria a promulgação de sentenças condenatórias, ao serem investidos de funçōes catárticas para as vítimas".

A discussão do papel da memória na construção das narrativas obtidas através das oitivas foi fundamental para a CMV-JP. Gwyn Prins, ao usar a expressão "reminiscências" em substituiçáo a "memória individual", enfatiza a importância dos relatos individuais, pela riqueza de informaçóes que possibilitam ao conformarem identidades:

A bioquímica da memória é ainda muito pouco compreendida. Mas testes sobre diferentes tipos de memória tendem a concordar que a memória de longo prazo, especialmente em indivíduos que entraram naquela fase que os psicólogos chamam de 'revisão de vida', podem ser notavelmente precisos. As pessoas adquirem um "poço de informaçóes" preenchido pelo relacionamento pessoal. É circunscrito a seu contexto social, obviamente forma a identidade pessoal e tem uma incrível estabilidade. [...] A revisão da vida é o produto final de uma vida de reminiscências. (Prins, 1992, p. 191-192).

Nesses termos, o fato dos depoentes se tratarem, em sua absoluta maioria, de pessoas de idade avançada foi de grande contribuição para a CMV-JP. As reminiscências trazidas foram, portanto, essenciais para o trabalho da Comissão, constituindo-se em rico material para futuras pesquisas conduzidas por outros historiadores e demais cientistas sociais em suas indagações a respeito do Brasil no século XX:

O que a reminiscência pessoal pode proporcionar é uma atualidade e uma riqueza de detalhes que de outra maneira não podem ser encontradas. Torna possível as histórias de grupo em pequena escala [...]. Isso dá aos historiadores os meios para escrever o que o antropólogo Clifford Geertz chamou de 'descrição densa': relatos ricamente tecidos que tem a profundidade e os contornos que permitem uma análise antropológica substancial. (Prins, 1992, p. 192-193).

A ensaísta argentina Beatriz Sarlo elaborou densa reflexão sobre a matéria e a natureza das narrativas de ex-militantes para comissóes da verdade nos países da América Latina, e na Argentina em particular, nos momentos posteriores às ditaduras. Para Sarlo, ao condenar o terrorismo de Estado e evocar o princípio democrático do "nunca mais" com relação às graves violaçóes de direitos humanos, "os atos de memória foram uma peça central da transição democrática" desses países, constituindo-se "como instrumento jurídico e como modo de reconstrução do passado” (Sarlo, 2007, p. 20).

Entretanto, entendendo o campo da memória como um terreno de conflitos, Sarlo alerta para a subjetividade e para a temporalidade da narração memorialística. Ou seja, se "a narraçấo inscreve a experiência numa temporalidade que não é a de seu acontecer [...], mas a de sua lembrança” (Sarlo, 2007, p. 25), tal lembrança também está impregnada de subjetividade, seja dos narradores, seja daqueles que lhes fazem 
perguntas que orientam seus depoimentos. Atentando para o caso argentino, Sarlo alerta para a possibilidade de persistência, nos relatos testemunhais, das ideias mobilizadoras da política nacional nos anos 1960 e 1970, momento histórico "fortemente ideológico, tanto na esquerda como na direita", que fazia as ideologias aparecerem "como sistemas fortes que organizavam experiências e subjetividades” (SARLO, 2007, p. 62). Assim, segue ela,

[...] o que se pergunta é: quanto do peso e da reverberação das ideias restou nas narraçóes testemunhais, ou melhor, que sacrifício do semblante intelectual e ideológico do movimento político social se impóe na narração em primeira pessoa de uma subjetividade da época? Quanto subsiste desse teor ideológico da vida política nas narraçóes da subjetividade? (Sarlo, 2007, p. 66).

Sarlo reconhece na memória das vítimas das violências das ditaduras "um bem comum, um dever [...] e uma necessidade jurídica e política" das transições à democracia, e afirma que a "confiança nos testemunhos das vítimas é necessária para a instalação de regimes democráticos e o enraizamento de um princípio de reparaçáo e justiça”" (Sarlo, 2007, p. 47). Entretanto, sempre considerando que "a subjetividade é histórica", Sarlo insiste que tais

[...] discursos testemunhais, sejam quais forem, são discursos e não deveriam ficar confinados numa cristalizaçâo inabordável. Sobretudo porque, em paralelo e construindo sentidos com os testemunhos sobre os crimes das ditaduras, emergem outros fios de narraçóes que não estâo protegidas pela mesma intangibilidade nem pelo direito dos que sofreram. (Sarlo, 2007, p. 47).

Voltando ao caso brasileiro, em que a realização da justiça pelos crimes praticados por agentes do Estado foi bloqueada pela Lei da Anistia (Lei $n^{\circ}$ 6.683/1979), que modelou a transição democrática e foi considerada válida pelo Supremo Tribunal Federal (STF) em 2010, os resultados da sua tardia CNV suscitaram a emergência ao debate público de "fios de narraçóes" que, antes de serem legitimados "pelo direito dos que sofreram", assumem uma postura de revisionismo histórico e de negação do autoritarismo. Se as primeiras vozes dessa narrativa foram os membros do Clube Militar, no Rio de Janeiro, rapidamente ela ganhou espaço na sociedade, até ser reassumida pelas próprias Forças Armadas, inclusive na campanha presidencial e, depois, no governo de Jair Bolsonaro.

Em geral, tal narrativa recupera o argumento dos vencedores do golpe de 1964 de que o ocorrido foi uma "revolução democrática" contra o "perigo comunista" e a "corrupção" que grassaria o governo João Goulart. Tal argumento, fundado no imaginário anticomunista dos militares e na crença que autoatribui a eles um papel "moderador" na República face aos "desmandos" dos civis (Castro, 2002), reaparece na Ordem do Dia publicada pelo Ministério da Defesa em 31 de março de 2020: 
Naquele período convulsionado, o ambiente da Guerra Fria penetrava no Brasil. [...] As instituiçóes se moveram para sustentar a democracia, diante das pressóes de grupos que lutavam pelo poder. [...] A sociedade brasileira, os empresários e a imprensa entenderam as ameaças daquele momento, se aliaram e reagiram. As Forças Armadas assumiram a responsabilidade de conter aquela escalada, com todos os desgastes previsíveis. [...] O Movimento de 1964 é um marco para a democracia brasileira. Muito mais pelo que evitou. (Azevedo e Silva, 2020).

Tal confronto público com a memória sobre a ditadura militar construída pela $\mathrm{CNV}$ - teórica e politicamente apoiada nos princípios da democracia e dos direitos humanos - pode ser entendido nos marcos do "terreno de conflitos" ao qual aludiu Sarlo.

Cabe também reforçar a posição de Le Goff que, entendendo a memória coletiva como "um instrumento e um objeto de poder", alerta:

A memória, onde cresce a história, que por sua vez a alimenta, procura salvar o passado para servir ao presente e ao futuro. Devemos trabalhar de forma que a memória coletiva sirva para a libertaçáo e não para a servidáo dos homens. (Le Goff, 1990, p. 411).

É nesses marcos que a "batalha de memória", instalada pelos negacionistas da ditadura militar contra a narrativa construída pela $\mathrm{CNV}$, deve ser situada.

\section{Cultura política e valores cristãos}

Nas oitivas conduzidas pela CMV-JP, um dos aspectos que sobressaíram dos depoimentos dos militantes comunistas é o partilhar de uma cultura política marcada pela influência dos valores cristáos e pela visáo de mundo na qual os ideais de igualdade e compaixáo assumem destaque. Muito embora cientes, como informa Thomson (2012), de que no momento das entrevistas se estabelece uma relaçáo dinâmica e dialógica entre entrevistador e entrevistado, que estimula lembranças e criaçôes de significados, e de que esse processo de rememoração pode suscitar o surgimento de complexas e inesperadas memórias no que toca ao papel exercido pela Igreja Católica na estrutura familiar, na formação dos depoentes e no seu ingresso na militância, destacamos que essas questôes emergiram espontaneamente em todos os relatos, de forma que a "composição" dessas reminiscências prescindiu da mediação pelos membros da CMV-JP. Assim, alguns depoentes destacaram sua relaçáo com a religiosidade cristá vivida desde tenra idade, mas enfatizaram a posição de crítica àquilo que viam como uma posiçấo dúbia da Igreja, marcada pela dissintonia entre o discurso dos religiosos e suas práticas cotidianas, o que os teria afastado do catolicismo, ingressando em seguida no PCB. Em outros depoimentos, emergiu o reconhecimento 
da importância de integrantes da ala progressista da Igreja para a adesão ao marxismo e ao PCB.

O relato do engenheiro Antonio Augusto de Almeida, de tradicional família católica da aristocracia açucareira do Brejo paraibano, é exemplar do dilema vivido pela percepção da contradição existente entre os valores cristãos apregoados nos ambientes religiosos e a situaçáo concreta do mundo em que vivia, marcada por injustiças e desigualdades sociais. Já na adolescência, ao retornar a sua casa, vindo dos estudos na capital, se via imerso em melancolia ao reencontrar antigos amigos de infância, filhos de moradores do engenho paterno, sem acesso à instrução, retratos nítidos da sociedade desigual em que vivia:

Eu chegava lá e não tinha aquele entusiasmo porque os meninos que foram meninos comigo, filhos dos moradores, estavam na mesma situação, analfabetos, já pegando na enxada e tudo. E eu chegava todo cheio, e os meninos vinham junto de mim: 'Você tem muita leitura!'. Umas perguntas assim que eu... aquilo me chateava demais e eu ficava assim, todo... perdia o entusiasmo de chegar lá por conta desse reencontro que me incomodava. E isso já na juventude quando eu era estudante do Liceu. (Antonio Augusto de Almeida, 2014).

Isso levava-o a questionar não só os valores familiares, como também toda a estrutura social existente, sobretudo à medida que se aprofundava nos estudos. Nas suas memórias, isso marcou sua personalidade na transiçáo da adolescência para a vida adulta:

Ainda estudante aqui no Liceu, umas aulas de História e tal, século XIX, manifestos comunistas. Aquilo tudo me impactou profundamente. Então, quando eu fui para Recife para fazer vestibular de Engenharia e estudar lá, eu já ia assim todo confuso como jovem. (Antonio Augusto de Almeida, 2014).

A vida do sindicalista bancário João Fragoso, oriundo de família de camponeses pobres do sertão, foi marcada por uma formação imbuída de valores e sentimentos de justiça social e de caridade cristá, transmitidos a ele e a seus seis irmáos por seus pais. Assim, a despeito de uma educação religiosa nos moldes católicos, a sua religiosidade decorreu muito mais dos valores vivenciados no cotidiano familiar do que pelo fato de seguir a ritualística da Igreja:

Sou de uma formação mais religiosa que cristá. Quando eu falo em formação religiosa, eu me refiro à prática religiosa em si, a frequência à missa, frequência aos sacramentos, à liturgia, às cerimônias religiosas. [...] Essa minha formação era mais religiosa do que cristá. Cristá no sentido de se colocar a serviço do outro ou mesmo se empenhar nas lutas pela justiça. Então a minha formação era mais religiosa. Mas, com o exemplo de meu pai, meus pais foram mais no sentido da gente tender a se empenhar na luta pela justiça. (João Fragoso, 2015). 
Um dos exemplos que lhe vêm à memória desse sentimento cotidiano de caridade cristá transmitido por seus pais e náo pela Igreja ocorreu ainda na infância, quando sua mãe acolheu três idosas, levou-as para partilhar uma refeição, gerando nos filhos um assomo de desagrado corrigido prontamente pelo exemplo dado por Cristo:

Perto de nós moravam três cidadãs idosas, doentes, o modelo, protótipo da exclusão. [...] Elas tinham o corpo coberto de chagas e exalavam um mal cheiro horrível e elas iam lá em casa. Então a minha mãe as acolhia. Minha mãe ouvia os queixumes delas e procurava aconselhar, abrir uma esperança naqueles coraçóes extremamente sofredores. Então, um dia elas foram lá em casa e minha mãe sempre dava o pouco que a gente tinha. E dava, distribuía com elas, partilhava com elas. Quando foi um dia, elas chegaram. Eu acho que as chagas estavam mais vivas do que nunca e ninguém suportava. Então na hora do almoço, minha mãe ouviu e na hora do almoço minha mãe levou para a modesta mesa nossa, junto conosco. Então meu irmão, um irmão meu, chamou minha mãe e disse assim: 'Mãe por que é que ela não almoça depois da gente? Ninguém aguenta esse mal cheiro horrível'. Entáo minha mãe chamou assim e botou a mão no ombro dele e apontou para o céu e disse: 'Meu filho, Ele disse que o que fizerdes ao menor desses é a mim que o fazes'. (João Fragoso, 2015).

Já o economista e professor Nelson Rosas cresceu numa família de tradição política na Paraíba, vinculada à Igreja Católica. Foi sua experiência como aluno do Colégio Marista Pio X, observando o comportamento dos padres da instituição, oposto aos preceitos contidos em suas pregaçóes, que levou Rosas a uma consciência crítica à Igreja.

Estudei em colégio de padre, no Pio X. Só que o que a gente via que devia ser a prática cristã e o que os padres faziam era absolutamente contraditório! Terríveis contradiçôes naquela que dizem: 'faça o que eu digo, não faça o que eu faço'. Isso eu via todo dia e a revolta foi aparecendo até o ponto que eu cheguei à conclusão que 'tava errado, alguma coisa 'tava errada. (Nelson Rosas, 2015).

Se para esses três militantes a crítica ao catolicismo os aproximou do PCB, por não enxergarem no seio da Igreja o vetor para a superaçáo das injustiças sociais, para o advogado Júlio César Ramalho (2015), filho de um conservador proprietário de terras, e para a artista plástica Marlene Almeida, foi a aproximaçáo com a Juventude Estudantil Católica (JEC), ala progressista dessa mesma Igreja, ${ }^{3}$ que os levou à militância política de esquerda. No caso de Júlio César, isso se deu na JEC do Colégio São Bento, de Olinda, onde, em 1964, cursava o ginasial. O seu interesse pela política já vinha de

A respeito do posicionamento da Igreja Católica no Brasil durante a ditadura militar, ver: Della Cava (1988) e Mainwaring (2004). 
1962, quando, com apenas 15 anos, acompanhou a campanha de Miguel Arraes ao governo do estado de Pernambuco. Quanto a Marlene Almeida, foi a aproximação com a JEC do Colégio Nossa Senhora das Neves, em Joáo Pessoa, que a levou a rever os valores católicos. Até então, Marlene naturalizara a ideia de que a divisão da sociedade entre ricos e pobres era funcional, sendo a pobreza algo inerente ao mundo, auxiliando os ricos a chegarem ao reino de Deus por meio da caridade.

Meu pai era muito religioso. Tinha um tio padre. A minha casa era bem pertinho da igreja e os padres viviam na minha casa. Quando eu era menina, eu pensava, acho que talvez pelo que eu aprendi, que o mundo era organizado e as pessoas nasciam pobres e outras ricas e isso era porque Deus queria. Inclusive para facilitar a entrada no céu dos ricos, pois os ricos só poderiam ir para o céu dando esmola e fazendo caridade. Entấo, os pobres que estavam pelas ruas, eles serviam para que os ricos alcançassem o céu. Isso ficou muito tempo na minha cabeça porque eu estava vivendo naquele mundo da esmola, achava muito bonito uma pessoa dar um tostáo, na época, uma moedinha que não servia para nada, de esmola. (Marlene Almeida, 2016).

Foi no contato de Marlene com padres, como Pe. Juarez Benício e Pe. Everaldo, inicialmente, na JEC e, posteriormente, na Juventude Universitária Católica (JUC), que ela desconstruiu sua visão naturalizada da desigualdade do mundo, pois eles afirmavam que a pobreza não era algo necessário e que os pobres tinham direito a uma vida diferente. A convivência com esses prelados permitiu a Marlene o acesso aos princípios teóricos do comunismo, identificados por ela como similares aos do cristianismo, o que a conduziu para a militância comunista.

Padre Juarez era a grande figura da JUC. Nós fomos para uma semana de estudos na cidade de Coremas. [...] Padre Juarez conseguiu hospedagem para todos lá. Tinha uma igreja que ele usava para celebrar uma missa todo dia e o seminário abordava o comunismo e o cristianismo. As aproximaçóes e as diferenças entre os dois pensamentos. E ele convidou pessoas do Rio, gente da UNE [União Nacional dos Estudantes], alguns que eram cristãos e alguns comunistas. E aí nós passamos uma semana lá. Eu me lembro que ao final a gente chegou a uma conclusão que a única coisa que separava comunista de cristáo era o materialismo. O resto era igual. (Marlene Almeida, 2016).

\section{Ingresso e militância no PCB}

Antonio Augusto de Almeida teve os primeiros contatos com militantes do PCB ao chegar a Recife, em 1953, para cursar a Faculdade de Engenharia. Por volta de 1955, 
ingressou na célula universitária do Partido, passando por uma formação doutrinária e recebendo as primeiras orientaçóes a respeito da relação com os movimentos sociais. Ao concluir os estudos, voltou à Paraíba e, em 1962, foi admitido pelo governo do estado no Conselho Estadual de Desenvolvimento (CED), onde começou a conhecer pessoas ligadas ao PCB que também trabalhavam no órgão.

No seu depoimento, Antonio Augusto revelou aspectos do funcionamento do Partido na Paraíba, bem como enumerou diversos dos seus integrantes em João Pessoa e no interior do estado. Espaço fundamental em seu extenso depoimento foi dedicado aos conflitos agrários ocorridos antes do golpe civil-militar na Paraíba, já que ele foi um espectador privilegiado por integrar o quadro de jornalistas do Terra Livre, periódico voltado para os camponeses, fundado em 1949 e editado em São Paulo pelo PCB. Como correspondente do Terra Livre, ele cobriu a marcha realizada pelas Ligas Camponesas nas imediaçóes do Engenho Miriri no final de 1963, onde o Exército montou um acampamento com a presença de material bélico que, até hoje, é rememorado por pessoas que, à época, eram crianças e assistiram as demonstrações de força dos militares. Antonio Augusto acompanhou, também, a greve dos canavieiros de dezembro de 1963, uma das mais bem-sucedidas em toda a zona canavieira da regiáo Nordeste, por garantir a paralisaçáo maciça dos trabalhadores (majoritariamente, assalariados) e ter contribuído para a adoção do salário-mínimo no campo (Aued, 1986; Moreira; Targino, 1997). O papel pedagógico exercido pela história oral através dos depoimentos prestados à CMV, que revelam aspectos da realidade desigual, injusta e violenta existente no país, mormente silenciados e ocultados pela narrativa oficial, como bem aponta Oliveira (2014), fica evidente ao nos depararmos com o depoimento de Antonio Augusto, que destacou a situação de subordinação dos camponeses aos ditames dos latifundiários e o papel de resistência exercido pelas Ligas Camponesas:

E os proprietários começaram a expulsar na marra, né? Chegavam lá, e as casinhas eram todas de palha, cobertas de palha e as paredes de taipa. E eles amarravam uma corda no anel principal da cumeeira e uma junta de boi puxava e derrubava a casa. E saíam as crianças nuas, às vezes só com um shortzinho, com um calçãozinho, e a mãe com os utensílios que ela conseguia pegar, fugiam apavoradas. E as Ligas organizaram uma passeata. Não só passeata, mas levar essas famílias de volta e construir as casas e botar as pessoas dentro das casas. (Antonio Augusto de Almeida, 2014).

A atriz Zezita Matos aproximou-se do PCB quando era estudante, em 1958, ao participar de um congresso estudantil em Campina Grande, onde conheceu seu futuro marido, Breno Matos, quadro juvenil do Partido. Foi através dele que Zezita entrou em contato com o PCB e com o teatro, uma vez que o rapaz também fazia parte do Teatro Popular de Arte. O nível de conscientizaçáo social e política de Breno contribuiu para que Zezita rememorasse imagens de sua infância, dotando-as de um sentido até 
então não percebido. Afinal, no ato de rememorar está implícita a possibilidade de se estabelecer operaçóes capazes de ressignificar experiências anteriormente vividas, atribuindo-lhes novos sentidos (Borges; Serres, 2014; Libermann, 2014). Assim, a violência e a opressão exercidas pelo latifúndio contra a população local passavam a ser identificadas pela jovem:

E começamos, ele começou a me mostrar um lado que eu desconhecia e aí foi quando eu comecei, logo de cara, a me lembrar do que eu via na minha infância, em Pilar, com os latifundiários, o que eles faziam com os fregueses do meu pai, e aí comecei a ver o mundo de uma forma diferente. (Zezita Matos, 2015).

A jovem atriz também passou a frequentar as reuniōes do Partido e a participar de um processo de formação conduzido por lideranças como Leonardo Leal, José Anísio Maia e Manoel Alves. Ao mesmo tempo, passou a desempenhar açóes práticas definidas pelo Partido, tendo ingressado na Campanha de Educação Popular (CEPLAR), ${ }^{4}$ trabalhando em campanhas de alfabetizaçáo de adultos e em cursos de costura para mulheres de bairros populares. Passou também a atuar junto às Ligas Camponesas, acompanhando Manoel Alves nas suas viagens aos diversos municípios do estado e se apresentando em espetáculos de rua voltados para os camponeses, nos quais as questóes sociais tinham destaque.

Estreei em outubro de 58, com o teatro de rua em cima de caminháo. A gente ia para as feiras e fazíamos esquetes, [...] e a gente criava, fazia a figura de Agnaldo Veloso Borges [poderoso latifundiário da região conhecida como Várzea do Paraíba], de todos os latifundiários, e a gente fazia cenas já relacionadas com isso. $\mathrm{E}$ as pessoas se divertiam. (Zezita Matos, 2015).

João Fragoso, após militar algum tempo na Ação Católica, ingressou no PCB em 1962. A seu juízo, a organização vinculada à hierarquia da Igreja demonstrava, no calor dos anos 1960, os limites de atuaçáo frente aos problemas sociais do país, e foi no "Partidáo" que Fragoso encontrou o espaço político para atuar conforme os valores do catolicismo social com os quais se identificava, o que o levou a tomar uma atitude de mudança radical na sua vida: substituir a militância junto às bases da Igreja Católica pela atuação vinculada ao Partido Comunista.

Eu era então da Ação Católica. Mas, sendo da Ação Católica, eu não tinha ouvido ninguém me falar daquela maneira sobre o trabalho a favor dos explorados. Não, ninguém tinha me falado nisso. [...] Nessa época eu tomo uma decisão importante

4 Vinculada ao governo do estado, a CEPLAR voltava-se para a educação de adultos com base no método de Paulo Freire (Porto; Lage, 1995). 
na minha vida, a decisão foi essa deixar a Ação Católica e ingressar no Partido Comunista. (João Fragoso, 2015).

\section{A repressão se instala}

Ao saber da eclosão do golpe em 1964, Marlene Almeida relata que ela e diversos companheiros do Partido se reuniram numa área remota da praia de Tambaú para definirem as açóes a serem tomadas. Lembraram-se de que na sede do Partido estavam guardados documentos que poderiam comprometer e identificar seus integrantes. Coube a Marlene a tarefa de ir resgatá-los e destruí-los, para o que contou com a colaboraçáo "discreta" do porteiro do edifício, em um claro indício que parcelas significativas da sociedade não comungavam com as medidas de arbítrio e repressão instituída pelos militares:

Tinha um senhor gordo lá que trabalhava como porteiro. [...] Quando eu cheguei, ele disse: 'O Exército veio aí, saiu e volta já. E me disse que não deixasse entrar ninguém. Mas você entra que eu não estou vendo. Corra lá que eu não 'tô vendo. Vá pelas escadas. Não vá pelo elevador. No elevador não pode que eu não posso ver'. (Marlene Almeida, 2016).

Em seguida, em decorrência das prisóes que se sucediam, a família de Antonio Augusto, noivo de Marlene à época, convenceu-o a se esconder numa fazenda no interior do estado. Mas as buscas que invariavelmente o Exército fazia à casa de Marlene fizeram com que Antonio Augusto se apresentasse ao $15^{\circ}$ Regimento de Infantaria (RI), local que se notabilizou pelas prisóes efetuadas na Paraíba nos primeiros momentos que se sucederam ao golpe.

Minha casa era um beco sem saída. [...] Então o Exército começou a ir lá em casa. Deixava um carro na Epitácio Pessoa, fechando logo da Epitácio, e descia com vários, com arma de grosso calibre, até. E meu pai doente do coraçáo e a minha mãe [...] eles entravam procurando coisa, procurando Antônio Augusto, e meu pai dizia que ele náo estava lá, que não sabia de mim. (Marlene Almeida, 2016).

Antonio Augusto ficou preso cerca de um mês e meio, entre o $15^{\circ} \mathrm{RI}$ e o $1^{\circ}$ Grupamento de Engenharia - outra guarnição do Exército na cidade -, permanecendo incomunicável nos primeiros dias. Ao cabo desse período, demitido do CED e com dificuldades para conseguir outro emprego, haja vista sua implicação em atividades "subversivas", ele, juntamente com colegas egressos do CED, montou um escritório para elaboraçáo de projetos para empresas que quisessem concorrer aos incentivos da Superintendência do Desenvolvimento do Nordeste (SUDENE). Já Marlene, que 
havia concluído o curso de Filosofia, tentou voltar à universidade para cursar didática e poder lecionar a disciplina. Contudo, assim como em diversas outras instituiçóes, a Universidade Federal da Paraíba (UFPB) sofreu um processo de intervenção e de expurgos, prevalecendo, naquele momento, um clima de perseguiçóes e vinditas dirigidas contra os desafetos dos golpistas, em seu afã de galgar espaços na estrutura acadêmica (Cittadino, 1993; CEV-PB, 2017). Alvo de um expediente sumaríssimo de perseguição, já que não havia formalmente nenhuma denúncia contra ela, Marlene, ao chegar no prédio da instituição, foi vista pelo Diretor da Faculdade que mandou um recado pelo bedel: "Eles mandaram dizer que a senhora fosse embora. Não viesse mais aqui. Não aparecesse, não botasse os pés aqui" (Marlene Almeida, 2016). As curtas e enfáticas palavras com que Marlene rememora a experiência traumática da sua expulsão expressam o sofrimento de uma jovem cujos sonhos profissionais foram interrompidos e a revolta frente aos responsáveis pela violência perpetrada. Nesse sentido, a CMVJP tornou-se um locus para o testemunho do seu trauma, possibilitou que os danos sofridos reverberassem no presente e encontrassem visibilidade, contribuindo para a construçáo de uma "cultura da memória" ainda táo incipiente em nossa sociedade (Seligmann-Silva, 2010).

Já o dentista e suplente de vereador pelo Partido Socialista Brasileiro (PSB) Leonardo Leal, segundo depoimento de sua cunhada, Ednalva Sena, além de perder o cargo de professor de odontologia da universidade, foi obrigado a abandonar casa, família e consultório. $\mathrm{O}$ fato é que Leal era uma importante liderança do $\mathrm{PCB}$ paraibano e, ao saber da eclosão do golpe, imediatamente fugiu para o interior de Pernambuco. O Exército e a polícia invadiram a casa em que ele morava com a mulher, a sogra, a cunhada e o filho. Armados de metralhadoras, montaram guarda e escavaram todo o quintal da residência, em busca de armas que pudessem estar escondidas. As armas não foram encontradas, mas os militares levaram livros, fotos e diversos documentos que comprovavam a "periculosidade" de Leal.

O Exército no terraço da minha casa com metralhadora, aquela agressividade, um quintal enorme da minha casa. Morava na Avenida Tabajaras, ali perto do Liceu. Agressividade. Aquela coisa no terraço, ninguém entrava. Sabe bandido? Pegar o bandido esperando, coisa horrível. E esperando que ele entrasse, alguma coisa. Ninguém podia entrar nem sair. (Ednalva Sena, 2015).

Inicialmente Leal refugiou-se num pequeno sítio no interior de Pernambuco. Após algum tempo, sua mulher, Edinha, foi com ele se encontrar. $\mathrm{O}$ único filho que tinham naquele momento, Carlos Vinicius, uma criança na faixa de dois anos de idade, ficou com a avó. Ficaram ali naquela situaçáo de refugiados, morando num casebre, vivendo da ajuda financeira de familiares, sobretudo de um tio que era militar. Posteriormente, seguiu para o Rio de Janeiro, passando a viver na semiclandestinidade. 


\section{Das marcas da violência}

A condução da vida após os reveses sofridos com a perseguição imposta pela ditadura militar, que implicou em perdas de sonhos, projetos e expectativas, e na adoção compulsória de mudanças nas trajetórias de vida, foi outro tema abordado ao longo das oitivas. Assim, o peso das frustraçóes e das decepçóes esteve presente nas memórias às quais a CMV forneceu a possibilidade da fala e da escuta (Pollak, 1989). Marlene Almeida relatou o clima de isolamento e solidão que a acometeu, já que os amigos militantes se afastaram uns dos outros, temendo denúncias e novas perseguiçôes. Por outro lado, ela e Antonio Augusto passaram a ser alvo de preconceito por parte de familiares e vizinhos por serem identificados como "perigosos comunistas". Os sonhos foram sufocados e as repercussôes foram profundas naquilo que garantia a sua identidade primordial, a arte, relegada a um pequeno espaço, sem visibilidade, em sua vida.

Eu deixei de ser artista, deixei de ser idealista, deixei de pensar que eu ia ensinar, que eu ia transformar o mundo. A gente virou nada, nós viramos palhas. [...] Pintava uns quadradinhos bem pequenos, um papelzinho de seis centímetros por três, mais ou menos, no máximo. E guardava dentro das gavetas, aquilo era inexistente. (Marlene Almeida, 2016).

O vazio que atingiu a sua vida - "Esse outro pedaço é um vácuo na vida da gente, é um vácuo. Só trabalhar pra comer, pra resolver problemas assim, não é? E sem condiçôes de se encontrar, de fazer algum trabalho. O trabalho artístico foi um buraco [...]" (Marlene Almeida, 2016) - se prolongou por longos 15 anos, só voltando a ser preenchido ao final dos anos 1970, quando da abertura política. Naquela ocasião, na busca de dar sentido à vida, Marlene voltou a pintar, trazendo para as telas as imagens que povoavam a sua memória, num processo de catarse dos seus medos e angústias.

Pintei muito alvo, o povo sendo alvo, como parte de um alvo. Pintei mulheres angustiadas, pintei o que eu via nas ligas camponesas, eu pintei exatamente aquela situação que eu estava vivendo e que eu, ao invés de estar na frente, eu estava lá atrás como alvo junto com aquelas multidóes. Eram multidóes sofridas, recortadas e foi a minha, minha primeira coragem que eu tive de aparecer foi em 79 com essa exposição. (Marlene Almeida, 2016).

Já Zezita Matos conseguiu canalizar para o teatro a energia que não podia mais expressar na militância, de forma que, para ela, foi através das atividades cênicas que conseguiu mobilizar o desejo de resistir à opressão. Muito embora sob a vigilância dos órgáos de censura e náo mais podendo se dedicar ao teatro politicamente engajado, nem participar do teatro popular de rua, Zezita nunca abandonou as temáticas sociais, 
a crítica ao universo político - feita de forma sutil - e a questão da mulher trabalhadora e nordestina nas peças das quais participou. Mas, as marcas do tempo sombrio da violência e da tortura continuaram a acompanhá-la ao longo dos anos. Em 2010, na preparação da montagem do espetáculo "Milagre Brasileiro", que denunciava aquele período do arbítrio, emocionava-se ao recordar das torturas sofridas pelo seu grande amigo Manoel Alves, um dos principais líderes do PCB paraibano.

A cena que eu me lembro de Manoel contando é tirana. É arrancando as unhas das mãos e dos pés dele. [...] Quando eu faço o Milagre Brasileiro [...] porque exatamente no grupo do teatro atual não tinha ninguém nascido em 64 . Somente eu. [...] Entâo pra mim foi muito forte ver, ler, por exemplo, Tortura Nunca Mais, que a gente leu, ouviu filmes, vários filmes de pessoas, depoimentos. (Zezita Matos, 2015).

Recomeçar a vida num novo ambiente, longe dos familiares, amigos e do trabalho, foi o que restou ao dentista Leonardo Leal. No Rio de Janeiro, para onde se mudou com a mulher e o filho pequeno, abandonou a identidade de "Leonardo Leal" e passou a usar o sobrenome do meio, tornando-se conhecido como "Dr. Moreira". Lentamente voltou às atividades profissionais, que passaram a ser exercidas apenas no consultório que conseguiu montar. Aos poucos reconstruía a vida, marcada, entretanto, pelos fantasmas da perseguição que o obrigavam a manter-se no anonimato e impediam a ele e a sua família de construir novas amizades, condenando-os a uma vida de desterro físico e emocional. Nos primeiros anos do exílio que se impôs a Leal, percebe-se os traços apontados por Said (2003): o desenraizamento e a privaçáo da terra natal, o medo neurótico e permanente que persegue o exilado e a solidáo por viver apartado dos seus.

E agora lá, ele continuou perseguido, continuava perseguido, ele continuou escondido, a vida não tinha amizade com ninguém, era igual a bandido mesmo. Morava ali, e saia sem falar com ninguém, não tinha, era uma vida terrível uma vida dessa, não é? [...] Clandestino total, então morava em lugar, não podia ter amizade, meu sobrinho não tinha amigos, não tinha nada. Porque a qualquer momento ainda poderia [...]. (Ednalva Sena, 2015).

\section{Considerações finais}

Permitir aos perseguidos políticos a reconstrução das suas experiências de vida relacionadas ao período da ditadura militar, cotejando-as com o espaço em que vivem atualmente e com as perspectivas frente ao mundo que os rodeia, redundou, para eles, na (re)afirmaçáo dos valores que os levaram a ingressar numa atividade política que, com a instalação da repressão, resultou na brutal desestruturação dos seus sonhos e 
da própria vida. Afinal, é pelo recurso à memória que se estabelecem identidades que atribuem sentido a indivíduos ou sociedades: "A memória é um elemento essencial do que se costuma chamar identidade, individual ou coletiva, cuja busca é uma das atividades fundamentais dos indivíduos e das sociedades de hoje, na febre e na angústia" (Le Goff, 1990, p. 410). Assim, para João Fragoso, sua vinculação ao PCB proporcionou-lhe respostas às suas inquietaçóes e angústias, bem como o espaço de sociabilidade e acolhimento. Rememorando o papel que o Partido desempenhou na sua vida, ele afirma:

[...] foi pra mim fundamental porque ele [o PCB] abriu os meus horizontes. Nesse sentido de ter uma consciência crítica da realidade. Não tinha. Pra mim, o mundo caminhava por si. Quer dizer, a história. Mas, a história caminhava por si porque a gente náo podia influenciar nela, nada. Mas o partido foi me abrindo os olhos pra isso. Não. A gente é que faz a história. Aos poucos, vai, recua, avança, lá vai e vai caminhando. Mas foi o partido que me abriu os olhos pra isso. [...] e foi uma experiência muito boa. Encontrei elementos, quer dizer, encontrei indivíduos, pessoas muito humanas, capazes de entregar sua vida por uma causa, pelos outros, para a transformação da sociedade. (João Fragoso, 2015).

Ao mesmo tempo, o enunciar dessa memória representou a afirmação de uma verdade que afronta e desafia poderes então constituídos, o que significa, para esses militantes, reposicioná-los frente às disputas políticas com agentes que outrora lhes impuseram severa derrota. Em outras palavras, representa, ainda, a possibilidade de, em momentos em que a memória é alvo de intensas disputas, reescrever a história a partir daquilo que é dito por indivíduos até então silenciados, rompendo as interdiçóes impostas pelas narrativas oficiais que condenam determinadas memórias ao espaço clandestino e subterrâneo (Pollak, 1989).

Nesse sentido, a CMV-JP, realizando a tarefa de justiça de transição, envidou esforços para desnudar as violências cometidas por agentes do Estado ao longo da ditadura militar, buscou restabelecer a verdade oculta e desfigurada por tantos anos de silêncio e, ao proporcionar a oportunidade de escuta e acolhimento a diversos daqueles militantes perseguidos pelo autoritarismo, nos limites das suas possibilidades, compôs uma memória histórica comprometida com os valores da democracia e dos direitos humanos.

\section{Referências}

ARTHUR, Paige. Como as "transiçóes" reconfiguraram os direitos humanos: uma história conceitual da justiça de transição. In: REÁTEGUI, Félix (Org.) Justiça de transição: manual para a América Latina. Brasília: Comissão de Anistia, Ministério da Justiça; Nova Iorque: Centro 
Internacional para a Justiça de Transição, 2011. p. 73-133.

AUED, Bernardete Wrublevski. A vitória dos vencidos: (Partido Comunista Brasileiro - PCB - e Ligas Camponesas, 1955-64). Florianópolis: Editora UFSC, 1986.

AZEVEDO E SILVA, Fernando. Ordem do Dia Alusiva ao 31 de março de 1964. Ministério da Defesa, Brasília, DF, 30 mar. 2020. Disponível em: https:/www.gov.br/defesa/pt-br/centrais-deconteudo/noticias/ultimas-noticias/ordem-do-dia-alusiva-ao-31-de-marco-de-1965. Acesso em: 24 maio 2021.

BAUER, Caroline Silveira. Como será o passado? História, historiadores e a Comissão Nacional da Verdade. Jundiaí: Paco, 2017.

BORGES, Viviane Trindade; SERRES, Juliane Conceição Primon. Narrativas sobre o velho leprosário: as entrevistas realizadas com pacientes/moradores do Hospital Colônia Itapuã (Viamão/RS). História Oral, v. 17, n. 1, p. 119-134, jan./jun. 2014.

CASTRO, Celso. A invenção do Exército brasileiro. Rio de Janeiro: Zahar, 2002.

CEV-PB - Comissão Estadual da Verdade e da Preservação da Memória do Estado da Paraíba. Relatório final. João Pessoa: A Uniāo, 2017.

CITTADINO, Monique. A UFPB e o golpe de 64. Cadernos da ADUFPB-JP, João Pessoa, n. 10, p. 1-46, 1993.

CMV-JP - Comissão Municipal da Verdade de João Pessoa. Relatório. João Pessoa: CCTA, 2020.

DELGADO, Lucília de Almeida Neves. História oral: memória, tempo, identidades. Belo Horizonte: Autêntica, 2010.

DELLA CAVA, Ralph. A Igreja e a abertura (1974/85). In: STEPAN, Alfred (Org.). Democratizando o Brasil. Rio de Janeiro: Paz e Terra, 1988. p. 231-273.

LE GOFF, Jacques. História e memória. Campinas: Editora da Unicamp, 1990.

LIBERMANN, Zelig. Tempo, memória e ressignificação. Revista Brasileira de Psicoterapia, Porto Alegre, v. 15, n. 3, p. 83-90, 2014.

MAINWARING, Scott. Igreja católica e politica no Brasil. São Paulo: Brasiliense, 2004.

MEIHY, Carlos Sebe B.; SEAWRIGHT, Leandro. Memórias e narrativas: história oral aplicada. São Paulo: Contexto, 2020.

MOREIRA, Emília; TARGINO, Ivan. Capitulos de geografia agrária da Paraíba. João Pessoa: Editora Universitária, 1997.

MOTTA, Rodrigo Patto Sá. Cultura política e ditadura: um debate teórico e historiográfico. Tempo e Argumento, Florianópolis, v. 10, n. 23, p. 109-137, jan./mar. 2018.

OLIVEIRA, Vanessa Veiga de. Análise das audiências públicas da Comissão Nacional da Verdade: apontamentos sobre a articulaçáo dos conceitos de história de vida, luta por reconhecimento e memória coletiva. Lumina, Juiz de Fora, v. 8, n. 2, 2014.

POLLAK, Michael. Memória e identidade social. Estudos Históricos, Rio de Janeiro, v. 5, n. 10, p. 200-212, 1992.

POLLAK, Michael. Memória, esquecimento, silêncio. Estudos Históricos, Rio de Janeiro, v. 2, n. 
3, p. 3-15, 1989.

PORTO, Dorinha de Oliveira; LAGE, Iveline Lucena da Costa. Ceplar: história de um sonho coletivo. João Pessoa: Secretaria de Educação e Cultura, 1995.

PRINS, Gwyn. História oral. In: BURKE, Peter (Org.). A escrita da história: novas perspectivas. São Paulo: UNESP, 1992. p. 163-198.

QUEIROZ, Maria Isaura Pereira. de. Relatos orais: do "indizível" ao "dizível". In: SIMSON, Olga Rodrigues de Morais von (Org.). Experimentos com histórias de vida: Itália-Brasil. São Paulo: Vértice/Revista dos Tribunais, 1988. p. 14-43.

SAID, Edward. Reflexóes sobre o exílio e outros ensaios. São Paulo: Companhia das Letras, 2003.

SARLO, Beatriz. Tempo passado: cultura da memória e guinada subjetiva. São Paulo: Companhia das Letras; Belo Horizonte: UFMG, 2007.

SELIGMANN-SILVA, Márcio. O local do testemunho. Tempo e Argumento, Florianópolis, v. 2, n. 1, p. 3-20, jan./jun. 2010.

SOIHET, Rachel; BICALHO, Maria Fernanda; GOUVÊA, Maria de Fátima S. Apresentação. In: SOIHET, Rachel; BICALHO, Maria Fernanda; GOUVÊA, Maria de Fátima Silva (Org.). Culturas políticas: ensaios de história cultural, história política e ensino de história. Rio de Janeiro: Mauad, 2005.

THOMSON, Alistair. Memory and remembering in Oral History. In: RITCHIE, Donald (Ed.). The Oxford Handbook of Oral History. Oxford: Oxford University Press, 2012. p. 77-95.

TOLENTINO, Marcos Oliveira Amorim. Os outros rostos de "La Noche de los Lápices": memória e testemunho dos sobreviventes de um episódio emblemático da repressão durante a última ditadura civil-militar argentina (1976-1983). História Oral, v. 17, n. 1, p. 89-117, 2014.

TOSI, Giuseppe; SILVA, Jair de Albuquerque e. A Justiça de Transição no Brasil e o processo de democratização. In: TOSI, Giuseppe et al. (Org.). Justiça de transiçâo: direito à justiça, à memória e à verdade. Joáo Pessoa: Editora da UFPB, 2014. p. 41-61.

ZYL, Paul van. Promovendo a justiça transicional em sociedades pós-conflito. In: REÁTEGUI, Félix (Org.) Justiça de transição: manual para a América Latina. Brasília: Comissão de Anistia, Ministério da Justiça; Nova Iorque: Centro Internacional para a Justiça de Transiçáo, 2011. p. 47-71.

\section{Fontes orais}

ALMEIDA, Antonio Augusto de [87 anos]. [set./out. 2014]. Entrevistadores: Maria Nazaré Zenaide, Marlene Almeida, Monique Cittadino, Rodrigo Freire de Carvalho e Silva. João Pessoa, PB, 18 set. 2014, 3 out. 2014, 10 out. 2014.

ALMEIDA, Marlene [79 anos]. [maio 2016]. Entrevistadores: Maria Nazaré Zenaide, Marlene Almeida, Monique Cittadino, Rodrigo Freire de Carvalho e Silva. João Pessoa, PB, 4 maio 2016.

FRAGOSO, João [90 anos]. [abr. 2015]. Entrevistadores: Maria Nazaré Zenaide, Marlene 
Almeida, Monique Cittadino, Rodrigo Freire de Carvalho e Silva. João Pessoa, PB, 20 abr. 2015. MATOS, Zezita [79 anos]. [jan. 2015]. Entrevistadores: Maria Nazaré Zenaide, Marlene Almeida, Monique Cittadino, Rodrigo Freire de Carvalho e Silva. João Pessoa, PB, 23 jan. 2015.

RAMALHO, Júlio César [74 anos]. [set. 2015]. Entrevistadores: Maria Nazaré Zenaide, Marlene Almeida, Monique Cittadino, Rodrigo Freire de Carvalho e Silva. João Pessoa, PB, 17 set. 2015.

ROSAS, Nelson [82 anos]. [nov. 2015]. Entrevistadores: Maria Nazaré Zenaide, Marlene Almeida, Monique Cittadino, Rodrigo Freire de Carvalho e Silva. João Pessoa, PB, 20 nov. 2015.

SENA, Ednalva [74 anos]. [maio 2015]. Entrevistadores: Maria Nazaré Zenaide, Marlene Almeida, Monique Cittadino, Rodrigo Freire de Carvalho e Silva. João Pessoa/PB. 29 maio 2015.

Recebido em 15/10/2020.

Versão final reapresentada em 13/02/2021.

Aprovado em 22/03/2021.

Contribuiç̧óes dos autores: a concepção e a redação inicial do texto ficaram a cargo de Monique Cittadino. Como ambos os autores trabalharam na Comissão Municipal da Verdade de João Pessoa, os trabalhos de pesquisa documental, pesquisa bibliográfica, realização das oitivas, gravação e transcrição dos depoimentos foram feitos em conjunto. Rodrigo Freire de Carvalho e Silva ampliou a discussão sobre Justiça e Transição.

Fonte de financiamento: nada a declarar.

Conflitos de interesse: nada a declarar. 